\title{
LAND PLANNING AND BUDGETING FOR INDUSTRY
}

\author{
AKEF ASADULLAH QUAZI
}

Fakulti Alam Bina

\section{RINGKASAN}

Perancangan guna tanah merupakan sebahagian besar daripada proses perancangan bandar dan amat penting memandangkan penawaran tanah di bandar adalah terhad. Teknik perancangan guna tanah sentiasa berubah serta menjadi bertambah sofistikated. Tetapi di dalam berbagai aspek perancangan bandar keadaan sedemikian tidak semestinya benar berlaku bagi negara-negara yang sedang membangun kerana profesion ini sendiri adalah baru di kalangan negaranegara berkenaan. Malaysia sebagai sebuah negara yang pesat membangun tidak memerlukan penggunaan sama ada data-data ataupun teknik-teknik analisa yang sofistikated di dalam menyelesaikan masalah perancangan bandar asalkan penyelesaian berkenaan boleh difahami oleh pihak pentadbir dan berguna dan sesuai di dalam konteks rancangan pembangunan bandar.

Kertas ini mengemukakan satu teknik perancangan dan belanjawan tanah yang mudah dan bagi kegunaan perindustrian. Memandangkan hasil daripada perancangan guna tanah ialah untuk mewrijudkan keseimbangan di antara penawaran dan permintaan, maka teknik ini akan (1) mengenal pasti tanah yang berpotensi bagi kegunaan perindustrian dari segi tapak dan perletakannya (2) menganggarkan permintaan berdasarkan kepada piawaian yang dirumuskan daripada keadaan semasa serta pola keperluan tanah masa depan bagi berbagai jenis industri.

\section{ABSTRACT:}

Landuse planning is a part of a larger process of urban planning, but is a very critical part because urban land is always in short supply. Landuse planning techniques have been changing very fast and gathering increasing amount of sophistication. But professional sophistication in various aspects of urban planning is neither possible, nor necessarily realistic in developing countries as the profession itself is new in those countries. In a rapidly developing country like Malaysia the demands on urban planners are such that they have to produce urban planning solutions which do not require much sophisticated sets of data or lengthy analysis, yet are easily understandable by decision makers, and are meaningful in the context of planned urban development.

This paper describes a simple yet meaningful technique of land planning and budgeting for industrial uses. Since the final task in landuse planning is to bring 
about a balance between supply and demand, the technique addresses itself to (1) identifying potential land for industry from the site and locational view point, and (2) estimating demand on the basis of standards derived from the existing as well as the likely future pattern of land requirement by various types of industries.

\section{LAND PLANNING \& BUDGETING FOR INDUSTRY}

Land being a fixed and immobile resource, is always in short supply for urban development. In a strictly physical sense no particular parcel of land is more attractive than any other, but it is the location or site which is of major signifi. cance from the view point of urban activities. The location of some parcel of land may bestow on them some special characteristics that a particular urban activity may demand. Therefore, the mere existence of huge chunks of land is no guarantee that a local authority will benefit, for example, from its industrial potential. Nor is there any assurance that private enterpreneurs would be attracted to set up plants. It is the quality of land available to industry that may determine, to a large extent, the rate of industrial expansion in a given area.

To meet the present and future demands for industrial land, a local authority need to have a reserve of industrially zoned land which should be substantial in quantity and suitable for plant construction, served (or potentially served) by utilities, and oriented to at least one major mode of transport. Therefore, from the view point of industries requirement, the orientation of a potential sit should be studied first.

\section{Site Orientation Study}

Industry requires proximity to speedy, cheap and efficient form of transportation routes for inward transport of raw materials, and outward distribution of their finished products. Therefore the first task should be to study all vacant lands, existing and potential (resulting from urban renewal), in terms of their relationship to primary routes of transportation, be it road, railway, or port and waterway.

It is also important to consider that in terms of location and distribution of manufacturing areas, a range of choice has to be provided. Three typologies of sites need to be catered for, and they are: (i) inner city sites, (ii) fringe sites, and (iii) dispersed sites. For inner city sites direct access to railway, intercity trucking routes, cargo airport are fundamental factors of consideration. In portbased urban areas, close proximity of the site to deep water channels and/or port is of crucial importance.

Site orientation study should lead to a classification and grouping of land intended for industrial use according to their orientation to highway, railway, or port. This basic orientation should be viewed as the primary factor for their attractiveness for industrial use.

\section{(a) Highway Orientation}

Vacant land as well as land that may be made available as a result of urban renewal, clearance or reclamation, situated within $4 \mathrm{~km}$ by road travel from a highway interchange (existing or committed) should be delineated as Highway Oriented Tracts.

\section{(b) Railway Orientation}

The task of delineating vacant land with railway orientation should be guided by the possibility of providing railway sidings up to $2 \mathrm{~km}$ from a railway station or from a railway track from which a siding could be branched. It must be noted that proximity to railway track or stàtion does not necessarily mean orientation to rail. The distance between a vacant tract and the mainline may be short, but if steep grades, stream or road barriers prevent the construction of a siding, the tract should not be considered oriented to rail

\section{(c) Port and Waterways Orientation:}

Port oriented tracts should be located on a body of water with a minimum depth of $2.75 \mathrm{~m}(9 \mathrm{ft})$. The effect of ebb and tide should be taken into consideration. While $2.75 \mathrm{~m}$ to $5.5 \mathrm{~m}$ deep draft water should be adequate for barge traffic, average depth of $12.5 \mathrm{~m}$ would be needed to allow passage of large oceangoing vessels generally needed to service port-using industry. It should further be noted that the development of deep draft potential depends of dredging also. The value of port oriented land for industrial use obviously accelerates when supported by rail and/or highway transportation linkup.

Many tracts of land may have more than one orientation in which case it will be necessary, for statistical reasons, to fit each tract into one classification or another so that there are no double-counting. However, multiple orientation, if found, should be emphasized by classifying supplemental orientation within a primary grouping. On the other hand land with no orientation should also be delineated.

\section{Site Suitability Study :}

Suitability of vacant tracts of land under the above groupings should then be measured by such other criteria as topography, soil characteristics, storm water drainage, utilities, access from major housing areas of the prospective labour force, landuse compatibility etc. According to good industrial land development practice, the following common principles are adhered to in assessing suitability of land for manufacturing activities:

1. A parcel of land is considered suitable if slopes are less than 5\%, and soil is firm enough to support contemporary types of industrial buildings. A limited Threshold Analysis exercise may be carried out to identify slope and soil 'thresholds'; and an industrial architect may be consulted on the feasibility of industrial structures on a given type of soil. In low-lying and reclaimed land intensive load-bearing capacity study should be carried out. 
2. Availability of selected utilities such as power, water and waste disposa inadequacy.

3. Easy access to the sites from major housing areas of the prospective labour force should be an important consideration. Inner city sites should be accessible to and from mass-transit facilities. Fringe and dispersed sites should (Attention should be paides force and of force and/or the quality of rapid transit facilities for commuters).

4. Compatibility with the surrounding landuses on the basis of Performance Criteria (how an industrial establishment actually behaves - is it nuisance or not), and not on the basis of a predetermined nomenclature

Each of the selected factors above may be given a rating of 1 to 5 in a scale of suitablity. These ratings should then be combined rof 1 to 5 in a scale of cation: Suitable, Potentially Suitable, and combifisuitability scoring and summary pate, and Marginally Suitable (see examples of

Example: Highway Oriented Sites:

\begin{tabular}{|c|c|c|c|c|c|c|c|c|c|c|}
\hline $\begin{array}{l}\text { Tract } \\
\text { No. }\end{array}$ & $\begin{array}{l}\text { Acre } \\
\text {-age }\end{array}$ & Topo & & & $\begin{array}{l}\text { itab } \\
\text { Wat }\end{array}$ & $\begin{array}{l}\text { Scor } \\
\text { Siew/l }\end{array}$ & ccess & patibility & $\begin{array}{l}\text { Total } \\
\text { Score }\end{array}$ & $\begin{array}{l}\text { Eva. } \\
\text { lua- } \\
\text { tion }\end{array}$ \\
\hline 1 & 125 & 5 & 5 & 2 & 2 & 4 & 3 & 4 & 25 & $s$ \\
\hline 2 & 50 & 4 & 3 & 0 & 2 & 0 & 1 & 0 & 10 & $M$ \\
\hline 3 & 100 & 5 & 5 & 4 & 0 & 0 & 4 & 3 & 21 & P.S. \\
\hline 4 & 75 & 2 & 5 & 0 & 0 & 0 & 1 & 2 & 10 & $\mathrm{M}$ \\
\hline 5 & 150 & 5 & 5 & 4 & 4 & 3 & 4 & 3 & 28 & $\mathrm{~s}$ \\
\hline
\end{tabular}

$\mathrm{S}=$ Suitable; P.S. $=$ Potentially Suitable $; \mathrm{M}=$ Marginal

Example: Summary classification

$\begin{array}{ccc}\text { Total } & \text { Suitable } & \begin{array}{c}\text { Potentially } \\ \text { Suitable }\end{array} \text { Marginal }\end{array}$

Highway Oriented

Port/Waterway Oriented

Railway Oriented

$$
\text { Total }
$$

Multiple Orientation

No Orientation
(Note: Site suitability study can be carried out also by using industrial Sieve Analysis technique which is similar in spirit and purpose to the method discussed above, but somewhat different in operation. The Kuala Lumpur Structure Plan team, reportedly, used the Sieve Analysis technique).

The supply of land with various degrees of suitability available at various sites, needs to be compared with the land demand of the various prospective industries. It must be pointed out here that land planning and budgeting is to be seen as an integral part of the overall land budgeting for all other landuses in the urban area. This implies that a 'land balance sheet' be prepared showing supply and demand of land over a perspective plan period $(20-25$ years). It will then be possible to show objectively at what point in future the supply of 'suitable' category of land will be exhausted, and when the 'potentially suitable' and 'marginally suitable' categories of land will have to be developed with additional cost. (The assumption here is that 'potentially suitable' and 'marginally suitable' industrial land can be developed with additional expenditure either on the improvement of the site itself, or on the accessibility factors, or both.) Thus, investment decision and the sequence of investment on land development for industrial uses can be settled in an objective manner. We, therefore, turn now to the task of estimation of land requirements for manufacturing activities.

\section{Space (land) Requirement Study:}

The study would consist of three distinct parts. (i) an inventory of the existing patterns of land utilization in manufacturing, (ii) understanding the future patterns of land utilizations/needs in industry, and (iii) on the basis of (i) and (ii), estimate the total land requirements.

(i) First it is necessary to identify the salient characteristics of existing manufacturing uses in the urban area. This may be done with the help of recorded official information on existing industrial densities i.e. the number of manufacturing employee per gross acre in a particular category of industry. (Gross refers to all land within the property lines of the plant including building areas, landscaped grounds, parking and loading areas, outdoor storage and disposal areas, and also half of all streets, slip-roads and/or highways bordering the property.*) This study of the existing pattern should provide enough materials to isolate the existing types of industrial densities.

In order to make the study more meaningful a grouping should be made according to density classes of manufacturing activities. A second type of grouping of density classes should be arranged to bring out any differential characteristics between the manufacturing density of (a) the inner city, and (b) the outlying areas. The first of these two types of grouping would show the density by manufacturing classes, while the second type would reveal any significant difference in landusing characteristics between inner city and out-lying manufacturing establishments.

* This definition as provided by Stewart Chapin is not universal. 
[Density classes of manufacturing activity will vary from one urban area to another depending on the size of the urban area. In smaller towns manufacturing activity may be so diversified with one each of a kind that classification would be meaningless. How. ever, in bigger metropolitan areas the inner city may be charac. teristically found to have 'land intensive industries' while the out. lying area will have 'land extensive industries'. It is only logical that intensive and extensive industries will be found to distribute themselves in inlying and outlying areas respectively in response to land cost.

In the US North-Central and Great Lake areas 'intensive' category is defined as those manufacturing activities which has 40 or more industrial worker per net industrial acre, and 'extensive' category applying to those activities with less than 40 employees per net acre.

In Philadelphia 50 workers per gross acre (147 workers per net acre) designate intensive activities, and 6 workers per gross acre (18 workers per net acre) would mean extensive activities. Whereas in British New Towns average density for all manufacturing is 30 workers per gross (112 net acre). These facts only show that trends and patterns of industrial landuse not only vary between countries but also within the same country.]

(ii) Having studied the existing patterns of industrial landuses, adaptations are to be made to set up new standards with which future industrial land requirement would be estimated. In order to accomplish the estimation in a comprehensive manner, the prospects for future manufacturing activity in the area should be determined. This should be done primarily on the basis of previous studies of the urban economy (Economic Base study, Location Quotient, Shift-Share Analysis etc.) and general rate of projected growth in manfacturing employment. Where the prospects for new manufacturing activities are indicated, modern day plant requirements will have to be unders tood on the basis of consultation with industrial engineers and manufacturing plant designers. Studying other situations where new industrial activities are already in operation may be a useful exercise. Careful consideration will have to be given to the extent of automation in a particular industry, and also to the ratio of white collar workers in manufacturing industries.

(iii) Industrial landuse standards derived from the study of the existing characteristic patterns, and modified on the basis of consultation with industrial engineers and technologists, should then be applied to the projected manufacturing employment under different categories. At this stage of the computation existing standards on plot ratio/floorarea ratio, plinth area/site coverage, and set-back/buffer regulations etc. will have to be taken into consideration, or new standards set and applied.

(See Appendix I for some comparative density standards).

In order to avoid the risk of double counting, the new (additional) manufacturing employment figure should be subtracted from the total manufacturing employment projected for the plan period. The difference obviously would indicate the old (existing) components. It is natural to assume that of these old manufacturing establishments, now located in the inner city, some would want to expand and/or move out to more spacious and accessible locations or they may be required to move out as a result of urban renewal altering the existing landuse. Therefore, allowances will have to be made for such future moves.

There still remains the need for 'contingencies' - in order to accommodate unforeseen demand, landuse planners should earmark additional suitable areas as 'Industrial Reserves'.

On the basis of the foregoing studies, total land demand for industrial expansion in inlying and outlying areas, as well as amongst the intensive and extensive types should be charted down, and a tentative allocation of land should be made accordingly. If the tentative allocation is found not in conformity with all other land uses, or if the supply of land is found to be less than the demand, then additional new sites will have to be identified, if necessary, even beyond the local authority boundary. It must be reiterated here that land planning and budgeting for industries must not be seen as an independent excercise; it must relate and conform to the overall landuse and transportation plan of the greater urban area in question.

The tentative allocation, if found in agreement with the overall landuse plan, may then be refined. In respect of refinement, certain performance characteristics such as (a) shift work, (b) levels of automation (c) ratio of white collar worker etc. in the projected manufacturing activities, as mentioned earlier, will have to be considered. For this, industrial surveys involving establishment by establishment study including interviews with the management will be necessary. Final allocation of land should be determined only on the basis of such empirical studies.

\section{Some Special Considerations:}

For potential 'industrial poles', it is important to have planned industrial districts with the same degree of rigorousness as that of residential or commercial districts. Usually such industrial districts are laid out in lots of varying sizes, minimum 5 acres, to accommodate modern industrial plant requirements. The concept of 'industrial park' is also very much in vogue in contemporary planning for industrial areas.

JERNEL TEKNOLOGI BIL. 3 JUN 83 
Planning of industrial parks are geared to create an attractive and pleasant environment on the basis of such provision as exhibition space, respectable eating places, control on architecture, landscaping and site planning, all other controls on visual compatibility and environmental pollution control.

In order to enhance the locational attractiveness, some local authorities have gone one step further to introduce the concept of 'industrial nurseries' where fixed modules of site and building types are provided for certain types of new industries to come and start operating right away on an experimental basis.

\section{Concluding Remark.}

The approach as well as the technique described above, it must be admitted, is a simplified one. There are land development models which are much more sophisticated and exacting than what is outlined above. But obviously those models would demand more precise information and specialized technical manpower which may not be available in the near future. In the meantime, a landuse planning team must make do with the kind of modest methodology as presented in this paper.
APPENDIX I

\section{Some Comparative Standards in Industrial Land Budgeting}

1. Ipswich, England:

\begin{tabular}{|c|c|c|c|c|c|}
\hline Area covered & 300 & $\mathrm{ft}$ /worker & 9000 & $\mathrm{sft} / \mathrm{a}$ & acre \\
\hline Area not covered & 700 &,$\quad$, & 21000 & , & \\
\hline Parking & 150 & $"$, & 4500 & $"$ & , \\
\hline Internal Roads & 300 & $" \quad$, & 9060 & & ", \\
\hline & & wor & 435 & sft & (1 acre) \\
\hline
\end{tabular}

(Net Density: 30 workers per acre)

2. Six New Towns around London:
Area covered
Area not covered
Parking
Internal Roads

(Net Density: (a) 67 workers/acre $\quad$ (b) 50 workers/acre)

Note: an average firm in the above sample took 10 years to expand from 30 to 50 workers per acre).

3. Stevenage New Town, England:

Manufacturing Industries Service Industry

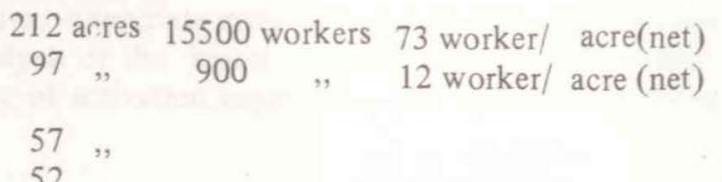
97 , $900 \quad, \quad 12$ worker/ acre (net) Undeveloped Roads etc.

(Plot ratio 5, maximum plot coverage 50\%, Structures should be at least $15 \mathrm{ft}$ away from plot boundary).

4. Seremban, Malaysia:

Floor area 1000 sft or less - No parking space needed Floor area above $1000 \mathrm{sft}$ :

1 parking bay for motorcars for every $1000 \mathrm{sft}$ of floor area or part thereof in access of the first $1000 \mathrm{sft}$ of floor area.

1 parking bay for scooters/motor cycles for every 4 employees.

JERNEL TEKNOLOGI BIL. 3 JUN 83 